\title{
In silico molecular docking of gallic acid as anti-photoaging
}

\author{
Ni Kadek Diah Parwati Dewi $\left(\mathbb{D}\right.$, Kadek Dinda Suryadewi $\mathbb{D}$, Diah Mawarni Fitriari $\mathbb{D}^{\mathbb{D}}$, \\ Kadek Lia Andini $\mathbb{D}$, Ni Putu Linda Laksmiani $\mathbb{B}^{*}$
}

Departement of Pharmacy, Faculty of Mathematics and Natural Science, Udayana University, Bukit Jimbaran, Badung, Bali 80361, Indonesia

*Corresponding author: Bukit Jimbaran Campus, Udayana University, Badung, Bali 80361, Indonesia. Email: laksmini@unud.ac.id

\begin{abstract}
Skin aging caused by excessive exposure to ultraviolet is known as photoaging. The mechanism underlying skin photoaging relates to collagen degradation in the extracellular matrix (ECM) by overexpression of matrix metalloproteinases-1 (MMP-1). Gallic acid is a phenolic antioxidant found in many types of plants and can be used as an anti-photoaging agent due to its antioxidant activity. This study aims to determine the potential effect of gallic acid as an anti-photoaging against MMP-1 using in silico molecular docking. The stages included gallic acid structure optimization using the HyperChem 8, preparation of protein target MMP-1 (PDB ID: 966C) using the Chimera1.10.1, validation the molecular docking protocol, and docking gallic acid on MMP-1 with the Autodock 1.5.6. The results showed that gallic acid had an affinity for MMP-1 with a binding energy of $-6.0 \mathrm{kcal} / \mathrm{mol}$. There are similar amino acid residues in hydrogen bonds between the RS2 native ligand with MMP-1 and gallic acid with MMP-1, namely ALA 182, LEU 181, and HIS 218. The results suggest that gallic acid has the potential as the anti-photoaging agent through the inhibition of the MMP-1 enzyme.
\end{abstract}

Keywords: anti-photoaging, gallic acid, in silico, MMP-1, molecular docking

\section{Introduction}

Aging is a physiological process that is caused by intrinsic and extrinsic factors. Intrinsic factors occur naturally with age, while extrinsic factors are associated with external exposure, such as ultraviolet light. Skin aging is caused by exposure to ultraviolet rays known as photoaging. Exposure to ultraviolet radiation causes the formation of reactive oxygen species (ROS) in the skin layer that triggers activator protein-1 (AP-1) activity. ROS inhibit the activity of receptor protein tyrosine phosphatases (RPTPs) by binding to cysteine at the catalytic site of RPTPs, increasing the level of phosphorylated receptor tyrosine kinases (RTKs) and triggering the activation of mitogen-activated protein kinase (MAPK), which in turn activates nuclear factor kappa-B (NF- $\mathrm{kB})$ and transcription factor AP-1. Induction of AP-1 will activate matrix metalloproteinases (MMPs) [1,2].

MMPs are a group of enzymes that have activity for degrading collagen. Excessive activity of MMPs can cause wrinkling, loss of skin elasticity, and sagging. The type of MMPs that play a significant role in collagen degradation in the extracellular matrix (ECM) structure is MMP-1. MMP-1 is an enzyme that can degrade type
I and type III collagen in the ECM [3]. Prevention of photoaging due to the overactivity of MMP-1 can be inhibited by anti-photoaging compounds, such as gallic acid.

Gallic acid or 3,4,5-trihydroxy benzoic acid is a phenolic compound found in most plants but is found in large amounts in green tea. Gallic acid is a phenol group of antioxidants with various pharmacological activities such as antioxidant, anti-inflammatory, anti-tyrosinase, anti-carcinogenic, anti-bacterial, antifungal, and photoprotective effects [4]. Its antioxidant activity can protect biological cells in the body from damage caused by oxidative stress [5-7]. Emblica officinalis aqueous extract containing gallic acid could protect human skin against oxidative stress by increasing the mitochondrial activity of human skin fibroblasts and increasing procollagen production [8]. Another study reported that grape stem extract containing gallic acid could reduce oxidative damage caused by UVB rays and prevent epidermal thickening, pigmentation, mast cell infiltration, and collagen degradation [9].

Inhibitory activity of gallic acid to MMP-1 can be determined through a preliminary test using the 
a

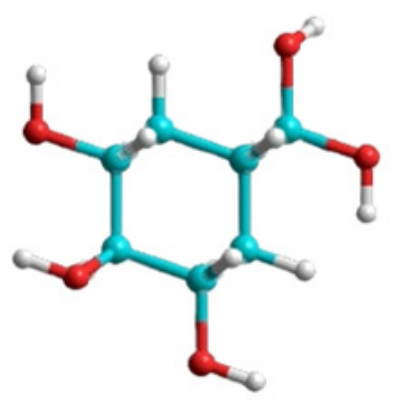

b

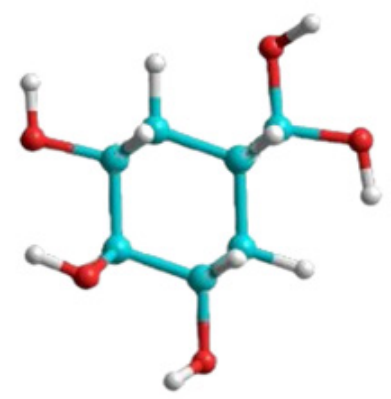

Figure 1. Result of optimized gallic acid structure. (a) single point calculation of gallic acid, (b) geometry optimization of the gallic acid

in silico molecular docking. This method is used to design and optimize drug lead compounds by computer and to calculate and predict the interaction between the molecule and protein [10]. Therefore, this study aims to determine the potential effect of gallic acid to inhibit MMP-1 using the molecular docking method.

\section{Methods}

\section{Gallic acid structure optimization}

The structure of gallic acid was downloaded from https://pubchem.ncbi.nlm.nih.gov/. Optimization of gallic acid was carried out using the HyperChem 8 program using Austin Model (AM1) semi-empirical computational method with single-point calculations and geometry optimization.

\section{Protein preparation}

The structure of protein target MMP-1 was downloaded from https://www.rcsb.org/. MMP-1 (PDB ID: 966C) was prepared by separating the protein from its native ligand using Chimera 1.10.1. A chain contains the native ligand, an MMP-1 inhibitor, $N$-hydroxy-2-[4-(4-phenoxy-benzenesulfonyl)tetrahydro-pyran-4-yl]-acetamide (ID: RS2) was used for docking study.

\section{Molecular docking validation}

The validation of the molecular docking was carried out by redocking the RS2 native ligand to the prepared MMP-1 protein using Autodock 4.2. The grid box size set and adjusted to $\mathrm{x}=60 \AA, \mathrm{y}=60 \AA \mathrm{z} \mathrm{z}$ $=60 \AA$; grid center $\mathrm{x}=9.166 \AA, \mathrm{y}=-10.353 \AA$, $\mathrm{z}=$ $38.398 \AA$. The value of root means square deviation (RMSD) $\leq 3 \AA$ indicates the protocol is accepted, and the docking of the test compound on the target protein can be carried out [11].

\section{Gallic acid docking on MMP-1}

The optimized gallic acid test compound was then docked to the prepared MMP-1 using Autodock 4.2 with the same grid box size during the validation step. The result of molecular docking is the binding energy and visualization of interaction [12]. The lower the bond energy, the stronger the interaction formed, which indicates the potential of the compound as an anti-photoaging agent [13].

\section{Results}

\section{Gallic acid structure optimization}

In the optimization process, single-point calculations and geometry optimization were carried out to obtain the most stable structure of gallic acid with the lowest total energy. The total energy generated from the single-point calculation of gallic acid compounds was $-2481.58 \mathrm{kcal} / \mathrm{mol}$. After geometric optimization, there was a decrease in the structural energy of gallic acid to $-2498.62 \mathrm{kcal} / \mathrm{mol}$ (Figure 1), indicating that a stable structure and lower energy were obtained.

\section{MMP-1 Protein preparation}

In this process, the MMP-1 protein was separated from RS2 native ligand to make the binding site available for the docking process of gallic acid. This process also aimed to obtain the RS2 native ligand structure used for the method validation process. One protein chain was selected to facilitate the determination of the coordinate space of the binding site where gallic acid binds during docking process. The prepared MMP-1 target protein without RS2 is displayed in Figure 2. 
a

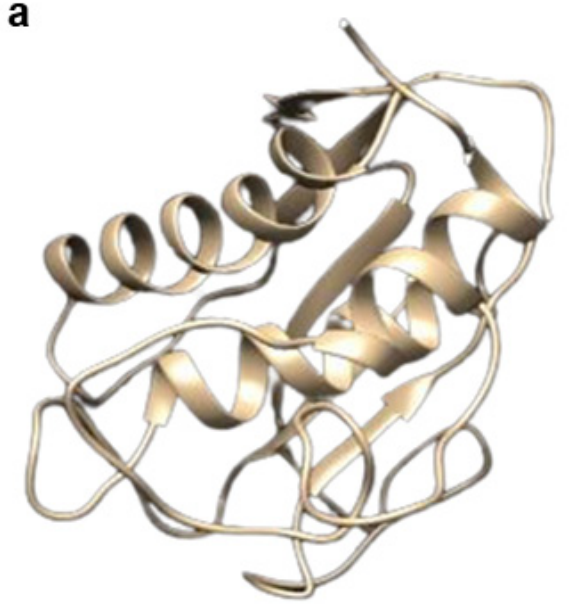

b

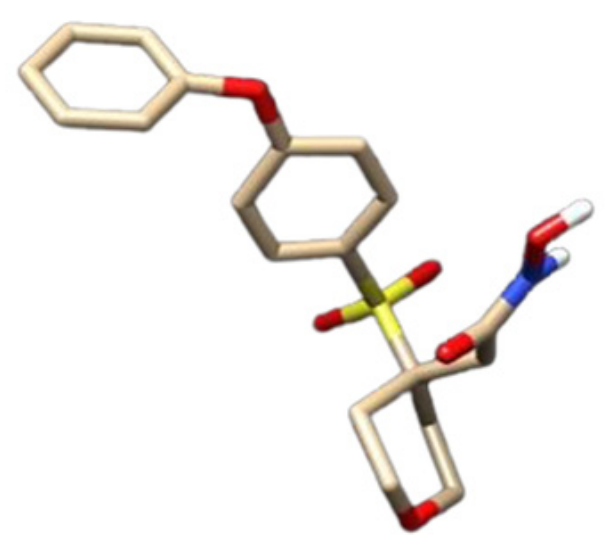

Figure 2. Protein preparation of MMP-1. (a) chain A of MMP-1 without RS2 native ligand, (b) RS2 native ligand

Table 1. The result of redocking RS2 on MMP-1

\begin{tabular}{|c|c|c|c|c|c|c|}
\hline Protein & Ligand & Conformation & $\begin{array}{l}\text { Bonding energy } \\
(\mathrm{kcal} / \mathrm{mol})\end{array}$ & RMSD (Å) & $\begin{array}{l}\text { Amino acid } \\
\text { residue }\end{array}$ & $\begin{array}{c}\text { Groups in } \\
\text { hydrogen bonds }\end{array}$ \\
\hline \multirow[t]{10}{*}{ MMP-1 } & RS2 & 1 & -8.79 & 2.27 & $\begin{array}{l}\text { HIS } 128 \\
\text { HIS } 228 \\
\text { LEU181 }\end{array}$ & $\begin{array}{l}\text { O38-HE2 } \\
\text { O38-HE2 } \\
\text { HN-O25 }\end{array}$ \\
\hline & & $2^{*}$ & -9.64 & 1.00 & $\begin{array}{l}\text { ALA182 } \\
\text { LEU } 181 \\
\text { HIS } 218\end{array}$ & $\begin{array}{l}\text { O25-HN } \\
\text { O26-HN } \\
\text { O31-HE2 }\end{array}$ \\
\hline & & 3 & -10.55 & 1.06 & $\begin{array}{l}\text { HIS } 218 \\
\text { HIS } 228 \\
\text { HIS } 222 \\
\text { ALA } 182\end{array}$ & $\begin{array}{l}\text { O31-HE2 } \\
\text { O31-HE2 } \\
\text { O31-HE2 } \\
\text { O25-HN }\end{array}$ \\
\hline & & 4 & -10.87 & 1.02 & $\begin{array}{l}\text { HIS } 218 \\
\text { HIS } 228 \\
\text { ALA } 182\end{array}$ & $\begin{array}{l}\text { O31-HE2 } \\
\text { O31-HE2 } \\
\text { O25-HN }\end{array}$ \\
\hline & & 5 & -10.71 & 1.03 & $\begin{array}{l}\text { HIS } 218 \\
\text { HIS } 228 \\
\text { LEU } 181 \\
\text { ALA } 182\end{array}$ & $\begin{array}{l}\text { O31-HE2 } \\
\text { O31-HE2 } \\
\text { O26-HN } \\
\text { O25-HN }\end{array}$ \\
\hline & & 6 & -8.72 & 2.18 & $\begin{array}{l}\text { HIS } 228 \\
\text { LEU } 181 \\
\text { ASN } 180\end{array}$ & $\begin{array}{c}\text { O38-HE2 } \\
\text { O25-HN } \\
\text { O31-HD21 }\end{array}$ \\
\hline & & 7 & -10.60 & 1.02 & $\begin{array}{l}\text { HIS } 218 \\
\text { HIS } 228 \\
\text { HIS } 222 \\
\text { ALA } 182\end{array}$ & $\begin{array}{l}\text { O31-HE2 } \\
\text { O31-HE2 } \\
\text { O31-HE2 } \\
\text { O25-HN }\end{array}$ \\
\hline & & 8 & -10.26 & 1.10 & $\begin{array}{l}\text { HIS } 218 \\
\text { HIS } 228 \\
\text { HIS } 222 \\
\text { ALA } 182\end{array}$ & $\begin{array}{l}\text { O31-HE2 } \\
\text { O31-HE2 } \\
\text { O31-HE2 } \\
\text { O25-HN }\end{array}$ \\
\hline & & 9 & -9.45 & 2.48 & $\begin{array}{l}\text { HIS } 218 \\
\text { HIS } 228\end{array}$ & $\begin{array}{l}\text { O38-HE2 } \\
\text { O38-HE2 }\end{array}$ \\
\hline & & 10 & -9.01 & 2.74 & $\begin{array}{l}\text { LEU } 181 \\
\text { ALA } 182\end{array}$ & $\begin{array}{l}\mathrm{O} 26-\mathrm{HN} \\
\mathrm{O} 25-\mathrm{HN}\end{array}$ \\
\hline
\end{tabular}


a

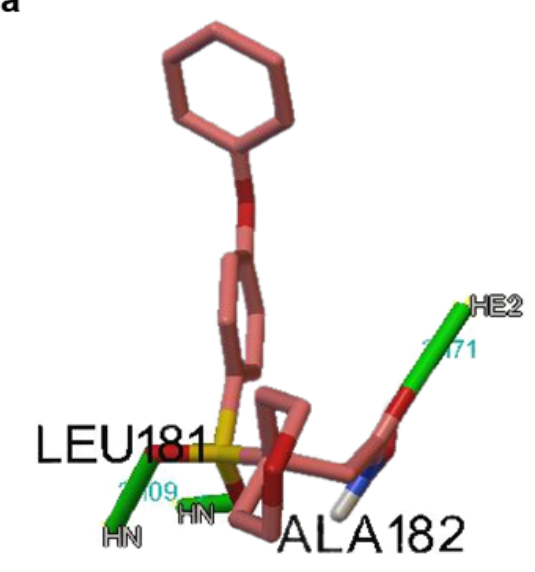

b

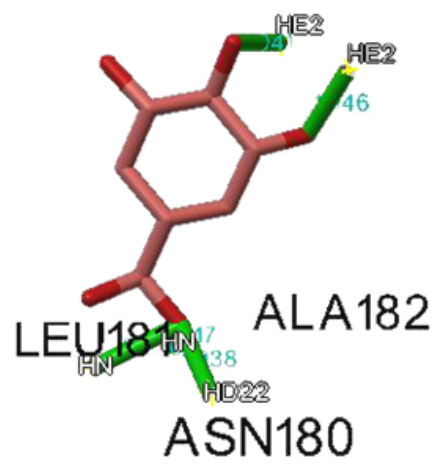

Figure 3. Docking of gallic acid to MMP-1. a) visualization of RS2 native ligand interaction with MMP-1, (b). visualization of gallic acid interactions with MMP-1

\section{Molecular docking validation}

The validation was carried out by redocking RS2 to MMP-1 to evaluate the deviations between the position or conformation of the native ligand before and after being re-docked. The minimum deviation can minimize errors in predicting the interaction during the molecular docking process. The validation process was started by the addition of hydrogen atoms to the target protein MMP-1. This step purposed to adjust the docking $\mathrm{pH}$ atmosphere as in the body [14].

The coordinates were arranged as grid center and grid size to determine the position of the protein binding site [25]. The redocking process was carried out using the semirigid method for macromolecules [15]. The redocking process was accepted and valid if RMSD value $\leq 3 \AA$. The redocking process produced ten conformational RS2 native ligand in the binding sites of target protein MMP-1 with different RMSD values and binding energies. Table 1 indicates that conformation 2 produced the lowest RMSD value (1.00 $\AA$ ) and met the validation requirements (RMSD $\leq 3 \AA$ ).

\section{Gallic acid molecular docking}

The optimized gallic acid structure was docked to the MMP-1 target protein using the same grid box size during validation to ensure the compound was docked at the active site. Table 2 indicates conformation 7 had the lowest binding energy $(-6.00 \mathrm{kcal} / \mathrm{mol})$ with the lowest RMSD.

\section{Interaction analysis}

The RS2 native ligand and gallic acid bound to MMP-1 through hydrogen bonds share similar amino acid residues. The hydrogen bonds occur in the amino acid residues alanine (ALA 182), leucine (LEU 181), and histidine (HIS 218) (Figure 3, Table 3). This similarity indicates that gallic acid occupied the target protein's active site in the same position as the RS2 native ligand.

\section{Discussion}

Our results showed that gallic acid has an affinity for the MMP-1 with binding energy $-6.0 \mathrm{kcal} / \mathrm{mol}$. Gallic acid and RS2 native ligand shared hydrogen bonding to MMP-1 with similar amino acid residues (ALA 182, LEU 181, HIS 218), suggesting that gallic acid docked to MMP-1 in the same coordinates of RS2 native ligand in the target protein.

Gallic acid exhibits skin protection from UVBinduced aging through negative modulation of MMP-1 secretion and positive regulation of type I procollagen in hairless mice [16]. Gallic acid was able to reduce the formation of wrinkles, thicken the epidermis, and increase skin hydration as well as regulate the expression of proteins responsible for the aging process. The latter is achieved by increasing the regulation of type I procollagen and elastin through stimulation of TGF-1 and reduction of MMP-1 expression thus has activity as an anti-photoaging agent [17].

Other phenolic compounds such as caffeic acid, chlorogenic acid, and ferulic acid, also showed inhibition activities towards MMP-1 protein. Using the similar methods and protein target (MMP-1, PDB ID 966C) with grid size $\mathrm{x}=30 \AA, \mathrm{y}=30 \AA \mathrm{z}, \mathrm{z}=30 \AA$ of RS2 native ligand, the binding energy of caffeic acid, chlorogenic acid, and ferulic acid were -7.1, -9.1, and 
Table 2. The result of molecular docking of gallic acid on MMP-1

\begin{tabular}{|c|c|c|c|c|c|c|}
\hline Protein & Ligand & Conformation & $\begin{array}{c}\text { Bonding } \\
\text { energy (kcal/ } \\
\text { mol) }\end{array}$ & RMSD (Å) & $\begin{array}{l}\text { Amino acid } \\
\text { residue }\end{array}$ & $\begin{array}{c}\text { Groups in } \\
\text { hydrogen bonds }\end{array}$ \\
\hline \multirow{33}{*}{ MMP-1 } & \multirow{33}{*}{ Gallic acid } & 1 & -5.93 & 0.05 & THR 241 & O-HN \\
\hline & & \multirow{6}{*}{2} & \multirow{6}{*}{-6.00} & \multirow{4}{*}{0.02} & ASN 180 & O-HD22 \\
\hline & & & & & LEU 181 & $\mathrm{O}-\mathrm{HN}$ \\
\hline & & & & & HIS 228 & O-HE2 \\
\hline & & & & & HIS 218 & O-HE2 \\
\hline & & & & \multirow{5}{*}{0.11} & ASN 180 & $\mathrm{O}-\mathrm{HD} 22$ \\
\hline & & & & & LEU 181 & $\mathrm{O}-\mathrm{HN}$ \\
\hline & & \multirow[t]{3}{*}{3} & \multirow[t]{3}{*}{-5.99} & & ALA 182 & $\mathrm{O}-\mathrm{HN}$ \\
\hline & & & & & HIS 228 & O-HE2 \\
\hline & & & & & HIS 218 & O-HE2 \\
\hline & & \multirow{5}{*}{4} & \multirow{5}{*}{$-5,99$} & \multirow{5}{*}{0.15} & ASN 180 & $\mathrm{O}-\mathrm{HD} 22$ \\
\hline & & & & & LEU 181 & $\mathrm{O}-\mathrm{HN}$ \\
\hline & & & & & ALA 182 & $\mathrm{O}-\mathrm{HN}$ \\
\hline & & & & & HIS 228 & O-HE2 \\
\hline & & & & & HIS 218 & O-HE2 \\
\hline & & \multirow{5}{*}{5} & \multirow{5}{*}{-6.00} & \multirow{5}{*}{0.02} & ASN 180 & $\mathrm{O}-\mathrm{HD} 22$ \\
\hline & & & & & LEU 181 & $\mathrm{O}-\mathrm{HN}$ \\
\hline & & & & & ALA 182 & $\mathrm{O}-\mathrm{HN}$ \\
\hline & & & & & HIS 228 & O-HE2 \\
\hline & & & & & HIS 218 & O-HE2 \\
\hline & & \multirow[t]{3}{*}{6} & \multirow[t]{3}{*}{-5.93} & \multirow[t]{3}{*}{0.04} & THR 241 & $\mathrm{O}-\mathrm{HN}$ \\
\hline & & & & & ASN 180 & O-HD22 \\
\hline & & & & & LEU 181 & $\mathrm{O}-\mathrm{HN}$ \\
\hline & & \multirow[t]{3}{*}{$7^{*}$} & \multirow[t]{3}{*}{-6.0} & \multirow[t]{3}{*}{0.00} & ALA 181 & $\mathrm{O}-\mathrm{HN}$ \\
\hline & & & & & HIS 228 & O-HE2 \\
\hline & & & & & HIS 218 & O-HE2 \\
\hline & & 8 & -5.94 & 0.00 & THR 241 & $\mathrm{O}-\mathrm{HN}$ \\
\hline & & \multirow[t]{3}{*}{9} & \multirow[t]{3}{*}{-5.93} & \multirow[t]{3}{*}{0.04} & THR 241 & $\mathrm{O}-\mathrm{HN}$ \\
\hline & & & & & ASN 180 & $\mathrm{O}-\mathrm{HD} 22$ \\
\hline & & & & & LEU 181 & $\mathrm{O}-\mathrm{HN}$ \\
\hline & & \multirow[t]{3}{*}{10} & \multirow[t]{3}{*}{-5.99} & \multirow[t]{3}{*}{0.02} & ALA 182 & O-HN \\
\hline & & & & & HIS 228 & O-HE2 \\
\hline & & & & & HIS 218 & O-HE2 \\
\hline
\end{tabular}

Table 3. Interaction of RS2 native ligand and gallic acid on MMP-1

\begin{tabular}{|c|c|c|c|c|}
\hline Protein & Ligand & $\begin{array}{l}\text { Bonding energy } \\
\text { (kcal/mol) }\end{array}$ & $\begin{array}{l}\text { Amino acid } \\
\text { residues }\end{array}$ & Groups in hydrogen bonds \\
\hline & RS2 native ligand & -9.64 & $\begin{array}{l}\text { ALA182 } \\
\text { LEU } 181 \\
\text { HIS } 218\end{array}$ & $\begin{array}{l}\mathrm{O} 25-\mathrm{HN} \\
\mathrm{O} 26-\mathrm{HN} \\
\text { O31-HE2 }\end{array}$ \\
\hline MMP-1 & Gallic acid & -6.0 & $\begin{array}{l}\text { ALA } 182 \\
\text { LEU } 181 \\
\text { HIS } 218\end{array}$ & $\begin{array}{l}\text { O-HN } \\
\text { O-HN } \\
\text { O-HE2 }\end{array}$ \\
\hline
\end{tabular}


$-7.0 \mathrm{kcal} / \mathrm{mol}$, respectively [18]. Another study using same protocol showed that ellagic acid has inhibition activities of MMP-1 protein, result in the binding energy was $-9.01 \mathrm{kcal} / \mathrm{mol}$ [19]. These two findings support that gallic acid as a phenolic compound is able to inhibit MMP-1 protein.

An in vitro study on the anti-skin aging activity of gallic acid was carried out through loaded gallic acid in neutral and cationic CTAB niosomes with vitamin $C$ as a positive control. The cationic CTAB niosomes loaded with gallic acid demonstrated the highest anti-skin aging activity, including antioxidant $(87.03 \pm 0.99 \%$ cell viability) and inhibition of matrix metalloproteinase- 2 (38.46 $\pm 1.53 \%$ of control) [20]. Another in vitro study on the inhibitory activity of gallic acid against MMP-1 in human nasopharyngeal carcinoma cells showed that gallic acid was able to inhibit the excessive production of ROS induced by UV light and was able to inhibit the activity of MMP-1 [21]. Other study examined gallic acid glucoside's potential as a cosmetic ingredient, including its antioxidant and anti-aging effects exerted by MMP-1 and collagen content. Gallic acid glycoside showed stronger anti-lipid peroxidation, anti-tyrosinase activity, and anti-aging function, with lower MMP-1 production but higher collagen content [22]. These findings support the evidence that gallic acid has antiphotoaging activity by inhibiting MMP-1, which could be useful in cosmetic and pharmaceutical preparations.

\section{Conclusion}

Gallic acid has potential as anti-photoaging agent in silico through the inhibition of the MMP-1. Further study is required such as molecular dynamics to support the anti-photoaging activity of gallic acid against MMP-1.

\section{Acknowledgment}

None.

\section{Funding}

The authors would like to express sincere gratitude towards Direktorat Jenderal Pembelajaran dan Kemahasiswaan Kementerian Riset, Teknologi, dan Pendidikan Tinggi Republik Indonesia that funded this research through 2021 Student Creativity Program (Program Kreativitas Mahasiswa 2021) (Grant number 015/E2/PPK/SPPK/PKM/2021).

\section{Declaration of interest}

The authors declare no competing interests.

\section{Author contributions}

NKDPD, KLA, NPLL conceptualized the study design, KDS and DMF investigated the data, NKDPD and KDS wrote the original draft, NKDPD, KLA, DMF, NPLL reviewed and edited the final version, NKDPD looked for the funding, NPLL supervised all experiments. All authors have read the final manuscript.

Received: 25 September 2021

Accepted: 3 December 2021

Published online: 4 December 2021

\section{References}

1. Kammeyer A, Luiten RM. Oxidation events and skin aging. Ageing Res Rev. 2015;21: 16-29. doi:10.1016/j. arr.2015.01.001

2. Rittié L, Fisher GJ. Natural and sun-induced aging of human skin. Cold Spring Harb Perspect Med. 2015;5: a015370. doi:10.1101/cshperspect.a015370

3. Xiao Z, Yang S, Chen J, Li C, Zhou C, Hong P, et al. Trehalose against UVB-induced skin photoaging by suppressing MMP expression and enhancing procollagen I synthesis in HaCaT cells. J Funct Foods. 2020;74: 104198. doi:10.1016/j.jff.2020.104198

4. Kahkeshani N, Farzaei F, Fotouhi M, Alavi SS, Bahramsoltani R, Naseri R, et al. Pharmacological effects of gallic acid in health and diseases: A mechanistic review. Iran J Basic Med Sci. 2019;22: 225-237. doi:10.22038/ ijbms.2019.32806.7897

5. Gao J, Hu J, Hu D, Yang X. A role of gallic acid in oxidative damage diseases: A comprehensive review. Nat Prod Commun. 2019;14: 1934578X1987417. doi:10.1177/ $1934578 X 19874174$

6. Queiroz MF, Sabry DA, Sassaki GL, Rocha HAO, Costa LS. Gallic Acid-Dextran Conjugate: Green Synthesis of a Novel Antioxidant Molecule. Antioxidants (Basel). 2019;8. doi:10.3390/antiox 8100478

7. Choubey S, Goyal S, Varughese LR, Kumar V, Sharma AK, Beniwal V. Probing gallic acid for its broad spectrum applications. Mini Rev Med Chem. 2018;18: 1283-1293. doi: $10.2174 / 1389557518666180330114010$

8. Naser W. The cosmetic effects of various natural biofunctional ingredients against skin aging: a review. Int J App Pharm. 2021; 10-18. doi:10.22159/ijap.2021v13i1.39806

9. Che DN, Xie GH, Cho BO, Shin JY, Kang HJ, Jang SI. Protective effects of grape stem extract against UVBinduced damage in C57BL mice skin. J Photochem 
Photobiol B, Biol. 2017;173: 551-559. doi:10.1016/j. jphotobiol.2017.06.042

10. Lin $\mathrm{X}, \mathrm{Li} \mathrm{X}$, Lin $\mathrm{X}$. A review on applications of computational methods in drug screening and design. Molecules. 2020;25. doi:10.3390/molecules25061375

11. Jain AN, Nicholls A. Recommendations for evaluation of computational methods. J Comput Aided Mol Des. 2008;22: 133-139. doi:10.1007/s10822-008-9196-5

12. Kitchen DB, Decornez H, Furr JR, Bajorath J. Docking and scoring in virtual screening for drug discovery: methods and applications. Nat Rev Drug Discov. 2004;3: 935-949. doi:10.1038/nrd1549

13. Du X, Li Y, Xia Y-L, Ai S-M, Liang J, Sang P, et al. Insights into Protein-Ligand Interactions: Mechanisms, Models, and Methods. Int J Mol Sci. 2016;17. doi:10.3390/ ijms17020144

14. Sastry GM, Adzhigirey M, Day T, Annabhimoju R, Sherman W. Protein and ligand preparation: parameters, protocols, and influence on virtual screening enrichments. J Comput Aided Mol Des. 2013;27: 221-234. doi:10.1007/ s10822-013-9644-8

15. Leis S, Zacharias M. ReFlexIn: a flexible receptor proteinligand docking scheme evaluated on HIV-1 protease. PLoS One. 2012;7: e48008. doi:10.1371/journal.pone.0048008

16. Zhao P, Alam MB, Lee S-H. Protection of UVB-Induced Photoaging by Fuzhuan-Brick Tea Aqueous Extract via MAPKs/Nrf2-Mediated Down-Regulation of MMP-1. Nutrients. 2018;11. doi:10.3390/nu11010060
17. Hwang E, Park S-Y, Lee HJ, Lee TY, Sun Z-W, Yi TH. Gallic acid regulates skin photoaging in UVB-exposed fibroblast and hairless mice. Phytother Res. 2014;28: 1778-1788. doi:10.1002/ptr.5198

18. Girsang E, Ginting C, Lister IN, Widowati W, Wibowo S, Perdana F, et al. In silico Analysis of Phytochemical Compound Found in Snake Fruit (Salacca zalacca) Peel as Anti-aging Agent. Thai Journal of Pharmaceutical Sciences (TJPS). 2019;43: 105-109.

19. Dewi NLPL, Ginarsih NMA. Molecular Docking Ellagic Acid As An Anti-Photoaging Agent In Silico. Acta Holistica Pharmaciana. 2021;3: 22-30.

20. Chaikul P, Khat-Udomkiri N, Iangthanarat K, Manosroi J, Manosroi A. Characteristics and in vitro anti-skin aging activity of gallic acid loaded in cationic CTAB niosome. Eur J Pharm Sci. 2019;131: 39-49. doi:10.1016/j. ejps.2019.02.008

21. Wu Y-Z, Tsai Y-Y, Chang L-S, Chen Y-J. Evaluation of Gallic Acid-Coated Gold Nanoparticles as an Anti-Aging Ingredient. Pharmaceuticals (Basel). 2021;14. doi:10.3390/ ph14111071

22. Nam S-H, Park J, Jun W, Kim D, Ko J-A, Abd El-Aty $\mathrm{AM}$, et al. Transglycosylation of gallic acid by using Leuconostoc glucansucrase and its characterization as a functional cosmetic agent. AMB Express. 2017;7: 224. doi:10.1186/s13568-017-0523-x 